\title{
Off label and unlicensed drug use among French office based paediatricians
}

\author{
M Chalumeau, J M Tréluyer, B Salanave, R Assathiany, G Chéron, N Crocheton, \\ C Rougeron, M Mares, G Bréart, G Pons
}

\section{Pharmacologie Périnatale et Pédiatrique, Université René Descartes-Paris V, Hôpital Saint-Vincent de Paul, 82, avenue Denfert-Rochereau, 75674 Paris Cedex 14, France \\ M Chalumeau \\ J M Tréluyer \\ G Pons \\ INSERM U149, Recherches Epidémiologiques sur la Santé des Femmes et des Enfants, Paris, France \\ B Salanave \\ G Bréart}

AREPEGE, Association pour la Recherche et l'Enseignement en Pédiatrie Générale, Versailles, France R Assathiany

Centre d'Urgence et de Diagnostic Rapide, Hôpital

Necker-Enfants

Malades, Paris, France G Chéron

Urgences Médicales de Paris, Paris, France

N Crocheton

Faculté de Médecine Paris-Ouest, Garches, France

C Rougeron

Faculté de Médecine Necker-Enfants Malades, Paris, France $M$ Mares

Correspondence to: Dr Pons

gerard.pons@

svp.ap-hop-paris.fr

Accepted 31 July 2000

\begin{abstract}
Aims-To determine the extent of off label and unlicensed drug use in French office based paediatric practice.

Methods-A prospective one day survey of all written prescriptions, for patients under 15 years, among 95 office based paediatricians in the Paris, France metropolitan area. Main outcome measures were: comparison of the use of each drug with its product licence for age, indication, dose, and route of administration. Results-A total of 2522 prescriptions were administered to 989 patients; 844 (33\%) were used either in an unlicensed $(4 \%)$ or an off label $(29 \%)$ manner. A total of $550(56 \%)$ paediatric patients received one or more off label prescriptions.

Conclusions-Off label prescriptions (that is, outside the terms of the Summary of Product Characteristics) are widespread in office based paediatric practice, while unlicensed drug use is rare in our study. New regulations in the licensing process in Europe are needed to allow children to receive drugs that have been fully evaluated in their specific age group.

(Arch Dis Child 2000;83:502-505)
\end{abstract}

Keywords: drug, approval; drug, utilisation; office visit; study, prospective

Unlicensed drug use and off label drug use (outside the terms of the Summary of Product Characteristics) in paediatric patients is a matter of concern among physicians caring for children, pharmacists, and pharmacologists. ${ }^{1-11}$

Nine hospital based studies have evaluated the extent of unlicensed and off label drug use among the paediatric population. ${ }^{12-20}$ Their results showed a high proportion of unlicensed drug use (around 10\%) or off label drug use (from $7 \%$ to $72 \%$ ). These surveys were undertaken in various hospital settings (general paediatric medical or surgical wards, ${ }^{12} 161819$ emergency departments, ${ }^{14}$ and paediatric ${ }^{13}$ or neonatal ${ }^{15}{ }^{17}{ }^{20}$ intensive care units).

However, most paediatric practice is provided outside hospital settings. To our knowledge, only three reports have evaluated unlicensed and off label drug use in office based paediatric practice (private practitioners in non-hospital settings). They all focused on specific aspects of prescriptions: newly marketed drugs, ${ }^{21}$ selective serotonin reuptake inhibitors, ${ }^{22}$ and children older than 4 years. ${ }^{10}$ It has been suggested that off label prescribing in office based paediatric care is low, around $10 \% .^{1023}$
We present the results of a one day survey of all written prescriptions of 95 office based French paediatricians, and the analysis of the prescription status with regard to their official licensed use in children in France.

\section{Patients and methods}

PAEDIATRICIANS' DATA

Written prescriptions for all patients under 15 years (the official age band between paediatric and adult patients in France) were collected prospectively, during a one day survey (Tuesday, 29 June 1999), in a continuous medical education (CME) group of paediatricians practising in the Paris metropolitan area. This group of 95 office based general paediatricians has been described elsewhere. ${ }^{24}$

\section{PRESCRIPTION SELECTION}

We excluded from the study prescriptions that did not require a licence (for example, functional foods, cosmetics, devices, and reagents). Sodium chloride nasal drops were excluded because they are over the counter medicines.

OFF LABEL STATUS

For each prescription, we collected data concerning the patient (date of birth, weight) and the drug (indication, dose, route of administration) to determine whether it had been used within the terms of the Summary of Product Characteristics. Each prescription was compared to the data available in the Dictionnaire Vidal. ${ }^{25}$ This publication is a convenient reference source for most physicians and pharmacists and the unique commonly available indirect source of information on the official Summary of Product Characteristics in France. For the ten most prescribed drugs, or when the Dictionnaire Vidal provided an ambiguous answer, the Summary of Product Characteristics was obtained from the Agence Française de Sécurité Sanitaire des Produits de Santé. We classified each off label prescription into four groups previously described in other studies $^{15-20}$ : age, indication, dose, or route of administration. We ascribed off label status for age to all drugs for which no specific dose regimen for paediatric patients was mentioned or for which specific age disclaimers were present. We tolerated up to $20 \%$ difference in dosing between the data sheet and the physician prescription, when determining the off label status for the dose. We did not find any discrepancy between the Summary of Product Characteristics and the Dictionnaire Vidal for the 15 different prescriptions that were double 
Table 1 The five most common indications

\begin{tabular}{lll}
\hline Indications & $\begin{array}{l}\text { No. of prescriptions } \\
(n=2522)\end{array}$ & $\begin{array}{l}\text { No. of off label drugs } \\
(n=745)\end{array}$ \\
\hline Vaccination & 385 & 63 \\
Fever & 328 & 19 \\
Common cold & 259 & 106 \\
Rickets prevention & 253 & 49 \\
$\begin{array}{l}\text { Dental caries } \\
\text { prevention }\end{array}$ & 172 & 15 \\
\hline
\end{tabular}

Table 2 The five most frequently prescribed drugs

\begin{tabular}{lll}
\hline $\begin{array}{l}\text { Proprietary } \\
\text { name }\end{array}$ & Constituent & $\begin{array}{l}\text { No. of prescriptions } \\
(n=2522)\end{array}$ \\
\hline Pentacoq & Pentavalent vaccine & 140 \\
Zymafluor & Sodium fluoride & 125 \\
Zyma-D2 & Ergocalciferol & 108 \\
Doliprane & Paracetamol & 108 \\
Efferalgan & Parpository) & 82 \\
\hline
\end{tabular}

checked. The age groups used were those defined by the European Agency for the Evaluation of Medicinal Products ${ }^{26}$ : neonates $(0-27$ days), infants ( 28 days to 23 months), children (2-11 years), and adolescents (12-17 years).

PAEDIATRICIANS' AWARENESS OF THE OFF LABEL STATUS

For each prescription, paediatricians indicated whether they had knowingly prescribed in an off label manner.

\section{STATISTICS}

The $\chi^{2}$ test was used to compare the number of off label prescriptions between different age groups.

ETHICS

Physicians were aware of the goal of the study. They were informed that no attempt would be made to judge the validity of their individual prescriptions. All data were collected anonymously with regard to patient and physician identity.

\section{Results}

Among the 95 paediatricians of the CME group, nine refused to participate and eight others did not return their questionnaire. One paediatrician's questionnaire was unusable. The participation rate was thus $81 \%$ (77/95). During the day of the survey, these 77 paediatricians examined 1093 children. We excluded 104 (9.5\%): 102 because they did not receive any prescription, and two because of missing data. The remaining 989 children received 2533 prescriptions. Eleven unreadable prescriptions were excluded. We therefore analysed a total of 2522 prescriptions.

The median age of the patients was 18 months (minimum 2 days, maximum 15 years). There were $49(5 \%)$ neonates, 512 $(52 \%)$ infants, 387 (39\%) children, and 41 (4\%) adolescents. Each paediatrician prescribed drugs on average to 13 children (SD 4, minimum four, maximum 25) on the study day. The median number of prescription by child was two (minimum one, maximum eight). Table 1 lists the five most common indications for prescribing. Table 2 lists the five most frequently prescribed drugs.

Four per cent $(99 / 2522)$ of the prescriptions were unlicensed and $29 \%(745 / 2522)$ were off label. One or more off label or unlicensed prescriptions were provided for 56\% (550/989) of patients. The reasons for ascribing off label status were: age $(65 \%)$, indication $(23 \%)$, dosage regimen $(10 \%)$, or route of administration $(7 \%)$. Six per cent of off label prescriptions were off label for more than one reason. Table 3 presents illustrative examples.

The extent of off label drug use in each of the age groups was: $70 \%$ in neonates, $27 \%$ in infants, $31 \%$ in children, and $36 \%$ in adolescents (table 4). Off label drug use was more frequent in neonates than in older children (relative risk 2.43, 95\% confidence interval 2.12 to $2.78, \mathrm{p}<10^{-7}$ ).

Off label drug use was very frequent $(64 \%)$ with the following "local" routes of administration: eye drops (94\%), ear drops (94\%), and topical skin preparations $(72 \%)$ (for examples, see table 3). Antibiotic eye drops represented $78 \%$ of off label courses of eye drops. These included rifampicin, aminoglycosides (for example, neomycin), and quinolones. All were off label because of the age of the patient. Antiseptic topical skin preparations represented the major group (38\%) of off label topical skin preparations, commonly chlorhexidine, hexamidine, triclocarban, and eosin. These were used in an off label manner in $86 \%$ of drug courses, again because of the age of the patient.

In most cases, paediatricians were not aware of the off label status of their prescriptions: only $8 \%$ of the 745 off label drug courses were suspected as such.

Table 3 Illustrative examples for each group of off label drug use

\begin{tabular}{|c|c|c|c|c|}
\hline Proprietary name & Constituent & $\begin{array}{l}\text { No. of off label } \\
\text { prescriptions }\end{array}$ & $\begin{array}{l}\text { Off label status } \\
\text { origin }\end{array}$ & Summary of Product Characteristics \\
\hline Ventoline $100 \mu \mathrm{g}$ & Salbutamol (MDI) & 25 & Age & $\begin{array}{l}\text { No advice for use in paediatric } \\
\text { population }\end{array}$ \\
\hline Rifamycine Chibret & Rifampicin (eye drops) & 18 & Age & $\begin{array}{l}\text { No advice for use in paediatric } \\
\text { population }\end{array}$ \\
\hline Isofra & $\begin{array}{l}\text { Framycetine } \text { (nasal } \\
\text { drops) }\end{array}$ & 13 & Age & $\begin{array}{l}\text { No advice for use in neonates and } \\
\text { infants }\end{array}$ \\
\hline Tridesonit & Désonide† (cream) & 7 & Age & Disclaimer for use in infants \\
\hline Mucomyst & Acetylcysteine $\ddagger$ & 26 & Indication & Restricted to bronchitis \\
\hline Clamoxyl & Amoxicillin & 10 & Dose & $\begin{array}{l}\text { Daily dose after } 30 \text { months: } 25-50 \\
\mathrm{mg} / \mathrm{kg}\end{array}$ \\
\hline HB VAX DNA $5 \mu \mathrm{g}$ & Hepatitis B vaccine & 27 & Route & Subcutaneous use not indicated \\
\hline
\end{tabular}

^Aminoglycoside nasal drops used in purulent rhinitis.

+Corticosteroid cream used in atopic dermatitis.

$\ddagger$ Mucolytic agent used in upper respiratory tract infections. 
Table 4 Off label drug use in the different paediatric age groups

\begin{tabular}{lcc}
\hline & $\begin{array}{l}\text { No. of } \\
\text { prescriptions }\end{array}$ & No. (\%) of off label prescriptions \\
\hline Neonates & 116 & $81(69.8)$ \\
Infants & 1327 & $357(26.9)$ \\
Children & 896 & $277(30.9)$ \\
Adolescents & 84 & $30(35.7)$ \\
Total & 2423 & $745(30.7)$ \\
\hline
\end{tabular}

\section{Discussion}

Our study shows that off label drug prescribing is common in office based paediatric practice in France, with nearly one third of all prescriptions off label for one or more reasons. More than half of the children received at least one off label drug course. We have not confirmed previous findings suggesting that the level of off label drug use in community paediatric practice was around $10 \% .^{1023}$

Off label drug use is paradoxically more likely to occur in neonates, an age group where safety requires the highest level of caution. During the neonatal period, transient immaturity of mechanisms involved in drug disposition requires careful evaluation of dose regimens used. Without this evaluation, the use of doses extrapolated from adult data could lead to adverse effects.

Another important result of the present survey is the extent of off label drug use with local routes of administration. Ninety four per cent of prescriptions for eye drops and $100 \%$ of those for antibiotic eye drops were off label. We were not able to find in the Dictionnaire Vidal, any antibiotic eye drops with advice for use in paediatric patients. The prescription of topical skin preparations encounters the same problem, with $72 \%$ of off label prescriptions. The higher surface area relative to body mass in children results in greater absorption of topically applied medicaments per unit of body mass. ${ }^{27}$ Various reports have shown the potential clinical consequences of this difference (for example, corticosteroids, hexachlorophene, iodine) ${ }^{27}$

Unlicensed drug use was rare-about $4 \%$ of all prescriptions. These primarily involved nasal drop preparations for the common cold. Some of these preparations contained epinephrine (adrenaline) or steroids which could be potentially harmful to children. ${ }^{28}$

Inappropriate prescribing was involved in some off label drug courses using an alternative route of administration (for example, subcutaneous hepatitis $\mathrm{B}$ vaccine injections) or in some unlicensed drug courses previously detailed, but this was uncommon. Lack of information for the use of drugs in children was responsible for $65 \%$ of the off label drug courses. We unsuccessfully searched for alternative drugs licensed for children in some situations, for example, antibiotic eye drops. Thus it is not possible to prescribe antibiotic eye drops that have been properly evaluated in children for safety and effectiveness with the same rigorous standards as in adult patients. Similarly, Avenel et al had systematically searched unsuccessfully for appropriately li- censed drugs in their study of off label drug use in a neonatal intensive care unit. ${ }^{20}$

Some selection bias may have affected our results. While the response rate was high $(81 \%)$, we were unable to evaluate the completeness of reporting by the physicians. Changes in prescription behaviour during the survey may also have occurred. These two last biases were also present in previously published studies on off label drug use.

Classification bias might also have occurred in relation to the difficulty in determining "off label" status of a prescription. The consensus between judges of the off label status of different drug regimens has been evaluated in only one study. ${ }^{12}$ Consensus level was low (55\%). In our survey, one paediatrician (MC) evaluated the status of all prescriptions. A 100 prescription sample was checked by a senior paediatric pharmacologist (JMT). There was no discrepancy.

One should be cautious in extrapolating the results of a one day survey to a full year. Seasonal variations in the type of diseases and thus perhaps prescriptions, occur in office based paediatric practice. The two seasonal events that we missed in the present survey were the winter respiratory syncytial virus and rotavirus epidemics. The first might involve off label prescribing of antibiotics, corticosteroids, or salbutamol, but the second is more likely to involve food than drug treatments. The overall off label drug use extent has probably been underestimated in our survey.

We have also studied (with the same methodology) the prescriptions of three groups of general practitioners and the prescriptions on discharge from a paediatric emergency department of a university hospital. As the response rates were low (32-60\%) or the total number of paediatric consultations was small in these groups, the corresponding data were not included in an overall analysis but can be used for comparison with the results of the present study. The extent of off label drug use among the prescriptions of general practitioners and emergency department doctors was $29.8 \%(132 / 443)$ and $40.7 \%(22 / 54)$ respectively. The percentage of paediatric patients who received one of more off label drugs was $53.2 \%(100 / 188)$ and $53.6 \%(15 / 28)$ respectively. These results did not differ significantly from those obtained in the CME group of paediatricians.

\section{CONCLUSIONS}

Off label drug use is widespread and common whatever the type of paediatric care, from neonatal intensive care units, to office based practice, through medical and surgical wards and in different countries. It clearly indicates that the origin of the problem is not related to inappropriate drug use by physicians but rather to an inadequate evaluation and registering process.

Children have the right to benefit from drugs which have been properly evaluated for safety and effectiveness in their age group, using standards as rigorous as those required for adult patients. In the USA, new Food and Drug Administration regulations became law 
in December $1998 .{ }^{29}$ It comprises financial incentives and legal obligations for paediatric drug evaluation for new and older drugs. European Community guidelines encourage drug manufacturers to apply for drug approval in children but have failed to improve labelling of drugs in children. ${ }^{8}$ We believe compulsory regulations are needed.

We gratefully acknowledge all the physicians who participated in this survey.

1 American Society of Hospital Pharmacists. ASHP statement on the use of medications for unlabeled uses. Am f Hosp Pharm 1992;49:2006-8.

2 American Academy of Pediatrics. Committee on drugs. Unapproved uses of approved drugs: the physician, the package insert, and the Food and Drug Administration: subject review. Pediatrics 1996;98:143-5.

3 Blumer JL. The therapeutic orphan-30 years later. A joint conference of the Pediatric Pharmacology Research Unit Network, the European Society of Developmental Pharm Network, the European Society or Developmental Pharma年 Human Development. Pediatrics 1999;104(suppl 3):581-

4 Nahata MC. Need for conducting research on medications unlabeled for use in paediatric patients. Ann Pharmacother

5 Kauffman RE. Status of drug approval processes and regulation of medications for children. Curr Opin Pediatr 1995; 7:195-8.

6 Kearns GL, Reed MD. Immediate action needed to improve labeling of prescription drugs for pediatric patients. Ann Pharmacother 1997;31:249-51.

7 Sutcliffle AG. Prescribing medicines for children. $B M \mathcal{F}$ 1999;319:70-1.

8 Impicciatore P, Choonara I. Status of new medicines approved by the European Medicines Evaluation Agency regarding paediatric use. Br 7 Clin Pharmacol 1999;48:1518.

9 Choonara I, Dunne J. Licensing of medicines. Arch Dis Child 1998;78:402-3.

10 Anonymous. Paediatric prescribing outside the licence-is there a problem? Pharmaceutical fournal 1998;261:62-3.

11 Bonati M, Choonara I, Hoppu K, Pons G, Seyberth H. Closing the gap in drug therapy. Lancet 1999;353:1625.

12 Thompson DF, Helfin NR. Frequency and appropriateness of drug prescribing for unlabeled uses in pediatric patients. Am f Hosp Pharm 1987;44:792-4.

13 Turner S, Gill A, Nunn T, Hewitt B. Use of "off label" and unlicensed drugs in paediatric intensive care unit. Lancet 1996;347:549-50.
14 McKinzie JP, Wright SW, Wrenn KD. Pediatric drug therapy in the emergency department: does it meet FDA-approved prescribing guidelines. Am 7 Emerg Med 1997;15:118-21.

15 Conroy S. Developments in relation to unlicensed and off label drug use. Paediatr Perinat Drug Ther 1998;2:23-6.

16 Turner S, Longworth A, Nunn AJ, Choonara I. Unlicensed and off label drug use in paediatric wards: prospective study. BMF 1998;316:343-5.

17 Conroy S, McIntyre J, Choonara I. Unlicensed and off label drug in neonates. Arch Dis Child Fetal Neonatal Ed 1999;80: F142-5.

18 Conroy S, Choonara I, Impicciatore P, et al. Survey of unlicensed and off label drug use in paediatric wards in European countries. BMF 2000;320:79-82.

19 Turner S, Nunn AJ, Fielding K, Choonara I. Adverse drug reactions to unlicensed and off-label drugs on paediatric wards: a prospective study. Acta Paediatr 1999;88:965-8.

20 Avenel S, Bomkratz A, Dassieu G, Janaud JC, Danan C. Incidence of prescriptions without product licence in a neonatal intensive care unit. Arch Pediatr 2000;7:143-7.

21 Wilton LV, Pearce G, Mann RD. The use of newly marketed drugs in children and adolescents prescribed in general drugs in children and adolescents prescribed in general practice.

22 Martin RM, Wilton LV, Mann RD, Steveson P, Hilton SR. Unlicensed and off label drug use for paediatric patients. General practitioners prescribe SSRIs to children off label. BMF 1998;317:204.

23 Collier J. Paediatric prescribing: using unlicensed drugs and medicines outside their licensed indications. $\mathrm{Br} \mathcal{F}$ Clin Pharmacol 1999;48:5-8.

24 Chalumeau M, Salanave B, Assathiany R, Kemeny J, Bréart $\mathrm{G}$, and the AREPEGE group. Office-based pediatricians' knowledge and adherence to a consensus statement on acute rhinopharyngitis in the child. Arch Pediatr 2000;7: 481-8.

25 Anonymous. Dictionnaire Vidal 1999, 1st edn. Paris: Editions du Vidal, 1999

26 European Agency for the Evaluation of Medicinal Products. Human Medicines Evaluation Unit. Committee for Proprietary Medicinal Products. Note for guidance on clinical investigation of medicinal products in children. London: EMEA, 1997.

27 Gupta A, Waldhauser LK. Adverse drug reactions from birth to early childhood. Pediatr Clin N Am 1997;44:79-92.

28 Damman Willems CE, Dinwiddie R, Grant DB, Rivers RP, Zahir M. Temporary inhibition of growth and adrenal suppression associated with the use of steroid nose drops. Eur 7 Pediatr 1994;9:623-4.

29 Food and Drug Administration. Regulations requiring manufacturers to assess the safety and effectiveness of new drugs and biological products in pediatric patients. Department of Health and Human Services, Food and Drug Administration. Federal Register December 1998, 63(231):66632-72.

\section{Rapid responses}

Letters on the following papers have been published recently as rapid responses on the $A D C$ website. To read these letters visit www.archdischild.com and click on "Read rapid responses":

Scrotal temperature is increased in disposable plastic lined nappies. C-J Partsch, M Aukamp, W G Sippell. Arch Dis Child 2000;83:364-8.

Why us? Why me? L Donovan. Arch Dis Child 2000;83:297.

Effect of oral glucocorticoid treatment on serum inflammatory markers in acute asthma. A Sahid El-Radhi, C L Hogg, Jatinder K Bungre, et al. Arch Dis Child 2000;83:158-62.

Dietary products used in infants for treatment and prevention of food allergy. J Salazar de Sousa, B Koletzko, A Host. Arch Dis Child 2000;83:87.

Corticosteroid therapy in nephrotic syndrome: a meta-analysis of randomised controlled trials. E M Hodson, J F Knight, N S Willis, et al. Arch Dis Child 2000;83:45-51.

If you would like to post an electronic response to these or any other articles published in the journal, please go to the website, access the article in which you are interested, and click on "eLetters: Submit a reponse to this article" in the box in the top right hand corner. 